Article

\title{
Identification of Ophiocordyceps sinensis and Its Artificially Cultured Ophiocordyceps Mycelia by Ultra-Performance Liquid Chromatography/Orbitrap Fusion Mass Spectrometry and Chemometrics
}

\author{
Ping Zhang ${ }^{1,2}{ }^{\mathbb{1}}$, Saina $\mathrm{Li}^{3}{ }^{3}$, Juan $\mathrm{Li}^{4}$, Feng Wei ${ }^{2}$, Xianlong Cheng ${ }^{2}$, Guifeng Zhang ${ }^{3}$, \\ Shuangcheng $\mathrm{Ma}^{2, *}$ and Bin Liu ${ }^{1, *}$ \\ 1 School of Chinese Material Medica, Beijing University of Chinese Medicine, No. 11Beisanhuan east Road, \\ Beijing 100029, China;zping0227@sina.com \\ 2 Research and Inspection Center of Traditional Chinese Medicine and Ethnomedicine, National Institutes for \\ Food and Drug Control, State Food and Drug Administration, No. 2 TiantanXili, Beijing 100050, China; \\ weifeng@nifdc.org.cn (F.W.); lncxl@sina.com (X.C.) \\ 3 State Key Laboratory of Biochemical Engineering, Institute of Process Engineering, Chinese Academy of \\ Sciences, No. 1 Second north Road of zhongguancun, Beijing 100190, China;seine2015@163.com (S.L.); \\ gfzhang@ipe.ac.cn (G.Z.) \\ 4 Institute of Microbiology, Chinese Academy of Sciences, No. 1 West Beichen Road, Beijing 100101, China; \\ 18612037125@126.com \\ * Correspondence: masc@nifdc.org.cn (S.M.); liubinyn67@163.com (B.L.); Tel.: +86-10-135-0139-8172 (B.L.); \\ Fax: +86-10-67023650 (S.M.)
}

Received: 25 March 2018; Accepted: 19 April 2018; Published: 26 April 2018

\begin{abstract}
Since the cost of Ophiocordyceps sinensis, an important fungal drug used in Chinese medicine, has increased dramatically, and the counterfeits may have adverse health effects, a rapid and precise marker using the peptide mass spectrometry identification system could significantly enhance the regulatory capacity. In this study, we determined the marker peptides in the digested mixtures of fungal proteins in wild $O$. sinensis fruiting bodies and various commercially available mycelium fermented powders using ultra-performance liquid chromatography/Orbitrap Fusion mass spectrometry coupled with chemometrics. The results indicated the following marker peptides: TLLEAIDSIEPPK $(m / z$ 713.39) was identified in the wild O. sinensis fruiting body, AVLSDAITLVR $(m / z 579.34)$ was detected in the fermented O. sinensis mycelium powder, FAELLEK $(m / z$ 849.47) was found in the fermented Ophiocordyceps mycelium powder, LESVVTSFTK $(m / z 555.80)$ was discovered in the artificial Ophiocordyceps mycelium powder, and VPSSAVLR $(m / z 414.75)$ was observed in O. mortierella mycelium powder. In order to verify the specificity and applicability of the method, the five marker peptides were synthesized and tested on all samples. All in all, to the best of our knowledge, this is the first time that mass spectrometry has been employed to detect the marker peptides of O.sinensis and its related products.
\end{abstract}

Keywords: Ophiocordyceps sinensis; ultra-performance liquid chromatography/Orbitrap Fusion mass spectrometry; chemometrics; fungi marker peptide; quality control

\section{Introduction}

Chongcao (the sexual stage of the Ophiocordyceps sinensis) is an important traditional fungal drug that has been commonly used for hundreds of years as a tonic and/or drug. However, its safety was questioned, because the wild Ophiocordyceps sinensis was reported to contain a high amount of arsenic likely due to soil contamination [1]. Then Ophiocordyceps sinensis had the clinical 
effect of tonifying the kidney and replenishing lung, stanching bleeding, and resolving phlegm. It could be used to treat 21 ailments and also be a potential adjuvant chemotherapeutic agent in non-small cell lung cancer, liver cancer, and breast therapy [2,3]. Despite the hazardous effects to the humanhealth, chongcao possesses manyanti-tumor and antioxidant activities, as well asthe capacity to modulate the immune system and treat fatigue, night sweating, hyposexuality, hyperglycemia, liver disease, and heart disease [4-9]. In recent years, due tothe limited natural resources and simultaneously increasing demand, thecost of $O$. sinensis has increased dramatically. In spite of the increasing price, its manufacture and sales were strictly regulated in 2016 by the China Food and Drug Administration (CFDA), because its natural fruiting bodies usually contain high amounts of arsenic, which is an environmental pollutant and could decrease neuronal migration, as well as cellular maturation, and it inhibits the proliferation of neural progenitor cells $[1,10]$. Considering the safe clinical use and the discrepancy between need and availability, other Ophiocordyceps-related fungi and the conidial forms of the artificially cultured $O$. sinensis fermentation mycelia have been used as substitutes in Chinese medicine and healthy food [11,12].

From the numerous species that have been reportedly isolated from $O$. sinensis $[13,14]$, it is widely accepted among researchers that Hirsutella sinensis is a unique anamorph of O. sinensis [11,15-17], while other species such as Paecilomyces hepialid, Gliocladium roseum, and Tolypocladium sinensis represent endoparasitic fungi commonly found in natural O. sinensis [18,19]. Currently, four species isolated from O. sinensis, namely, fermented O. sinensis mycelium powder (Hirsutella sinensis species), fermented Ophiocordyceps mycelium powder (Paecilomyces hepialid species), artificial Ophiocordyceps mycelium powder (Gliocladium roseum species), and O. mortierella mycelium powder (Tolypocladium sinensis species), all of which are usually confused with the $O$. sinensis name, have been successfully cultured. Four more standardized mycelia fermentation products of Ophiocordyceps have been produced [20-24] and are widely employed as Chinese medical material in preparations in China [25].

Since different Ophiocordyceps species may have different health effects, authentication of O. sinensis-related products is essential in order to ensure safeuse and efficacy. Traditionally, O. sinensis is identified through morphological description, microscopic identification, or chemical composition assay [23,26-29]. However, since these methods lack objective standards or a specific component index, it is difficult to effectively identify and distinguish $O$. sinensis from various cultured $O$. mycelia [30-34]. Furthermore, although the polymerase chain reaction (PCR) has been successfully applied in the identification of Ophiocordyceps sinensis (O.S.) fruiting bodies [14,15,35], it cannot be used for cultured Ophiocordyceps mycelia, because the integrity of the DNA genome is compromised during the drying process $[18,36,37]$.

Since species identification is an important and necessary procedure to control the quality and standardization of herbal medicines, it is crucial to develop methods to authenticate $O$. sinensis and the four aforementioned cultured $O$. mycelia. One approach to that could be the detection of the fungal proteins in the species. The fungal protein is a special protein, the amino acid sequence of which is different in the different fungi, thereby making it an important factor in the identification of species [38,39]. Moreover, these proteins are among the bioactive components in O.S. and, to the best of our knowledge, have rarely been studied and reported [40]. Biological mass spectrometry has been developed as an efficient method for proteomic analysis that exhibits superior mass accuracy and ultra-high resolution, and employs a segmented quadruple mass filter with improved selectivity and ion transmissibility [38,39,41-46]. However, for a specific genus, there is only limited data available to characterize the fungal protein. One example is the marker peptide in the digested mixture of O. sinensis-related products.

In this study, we first determinedthe digested mixture peptides by ultra-performance liquid chromatography/Orbitrap Fusion mass-spectrometry (UPLC/MS/MS). Then, the marker peptide ion was detected using chemometrics, and the marker peptide sequence was confirmed by comparisonwith the database for the identification of $O$. sinensis and relevant cultured Ophiocordyceps mycelia. The results demonstrated that this method could be used to authenticate not only wild $O$. sinensis 
and its related cultured Ophiocordyceps mycelia powder but also the mixed commercial products. Moreover, the work presented herein is, to the best of our knowledge, the first extensive study on the authentication of $O$. sinensis and cultured Ophiocordyceps mycelia using mass spectrometry and chemometrics, thereby providing a powerful quality control tool.

\section{Results}

\subsection{Size-Exclusion Chromatographic Analysis ofFungal Proteinsand Their Tryptic Digest Mixtures}

Figure 1 shows the size-exclusion chromatograms (SEC) of fungal proteins in fermented O. sinensis mycelia and the sample aliquots withdrawn during the digestion process. It was found that the fungal proteins had a wide molecular weight range (Figure $1 \mathrm{~A}$ ). When the amount of trypsin was increased, the peak intensities arising from the digest mixture gradually increased, indicating that more peptides in the mixture were degraded (Figure 1B-D). Once the sample-to-trypsin ratio exceeded 100:10, no significant changes in the peak intensity in the elution profile were observed (Figure $1 \mathrm{E}$ ). The molecular-weight ranges of the fungal proteins and the digest mixtures incubated at $37^{\circ} \mathrm{C}$ for $18 \mathrm{~h}$ were assessed against a series of protein standards, namely immunoglobulin $\mathrm{G}$ (molecular weight $\left(M_{W}=150 \mathrm{kDa}\right)$, bovine albumin $\left(M_{W}=68 \mathrm{kDa}\right)$, globular actin $\left(M_{W}=42 \mathrm{kDa}\right)$, trypsinogen $\left(M_{W}=24 \mathrm{kDa}\right)$, lysozyme $\left(M_{W}=14 \mathrm{kDa}\right)$, and bovine insulin $\left(M_{W}=6 \mathrm{kDa}\right)$, which were analyzed by SEC under the same conditions. The results revealed that the molecular weights of the fungal proteins ranged from 42 to $14 \mathrm{kDa}$, whereas the molecular weights of the peptides in the digest mixture were $<5 \mathrm{kDa}$, which is consistent with the theoretical molecular weight range of peptides resulting from the digestion of fungal proteins [47].

\subsection{Multivariate Data Analysis}

The total ion chromatograms (TICs) of the wild O. sinensis and four cultured Ophiocordyceps mycelia fungal proteins digested at $37^{\circ} \mathrm{C}$ for $18 \mathrm{~h}$, over the $350-1550 \mathrm{~m} / \mathrm{z}$ scan range, are displayed in Figure 2. The results show that the marker peptides of each mycelium were concealed by a large number of tryptic peptides that were indistinguishable in the TICs at higher concentrations due to the homologies of the fungal proteins. As a consequence, the different types of mycelia were difficult to detect simply by visual inspection of their chromatograms, and further sample profiling of the digest mixtures was performed using multivariate statistical software tools. In this study, the three-dimensional (3-D) ultra-performance liquid chromatography/Orbitrap Fusion mass-spectrometry (UPLC/MS/MS) data were first converted into a 2-D matrix containing exact-mass/retention-time (EMRT) pairs using the Progenesis QI for Proteomics, which is the application manager for Progenesis $\mathrm{QI}^{\mathrm{TM}}$. The data set was visualized using unsupervised principal component analysis (PCA) in order to check for outliers and classification trends among the mycelia. Preliminary PCA was performed on all observations using pareto-scaled variables. The final PCA score plot revealed that five different types of mycelia clusters formed, all of which lay inside the Hotelling T2 (0.95) ellipse (Figure 3a). In the PCA scores plot, the fermented Ophiocordyceps mycelia powder and $O$. mortierella mycelia powder lay close to each other but were located much further away from the wild O. sinensis, the fermented O.S. mycelia powder, and the artificial Ophiocordyceps mycelia powder. 

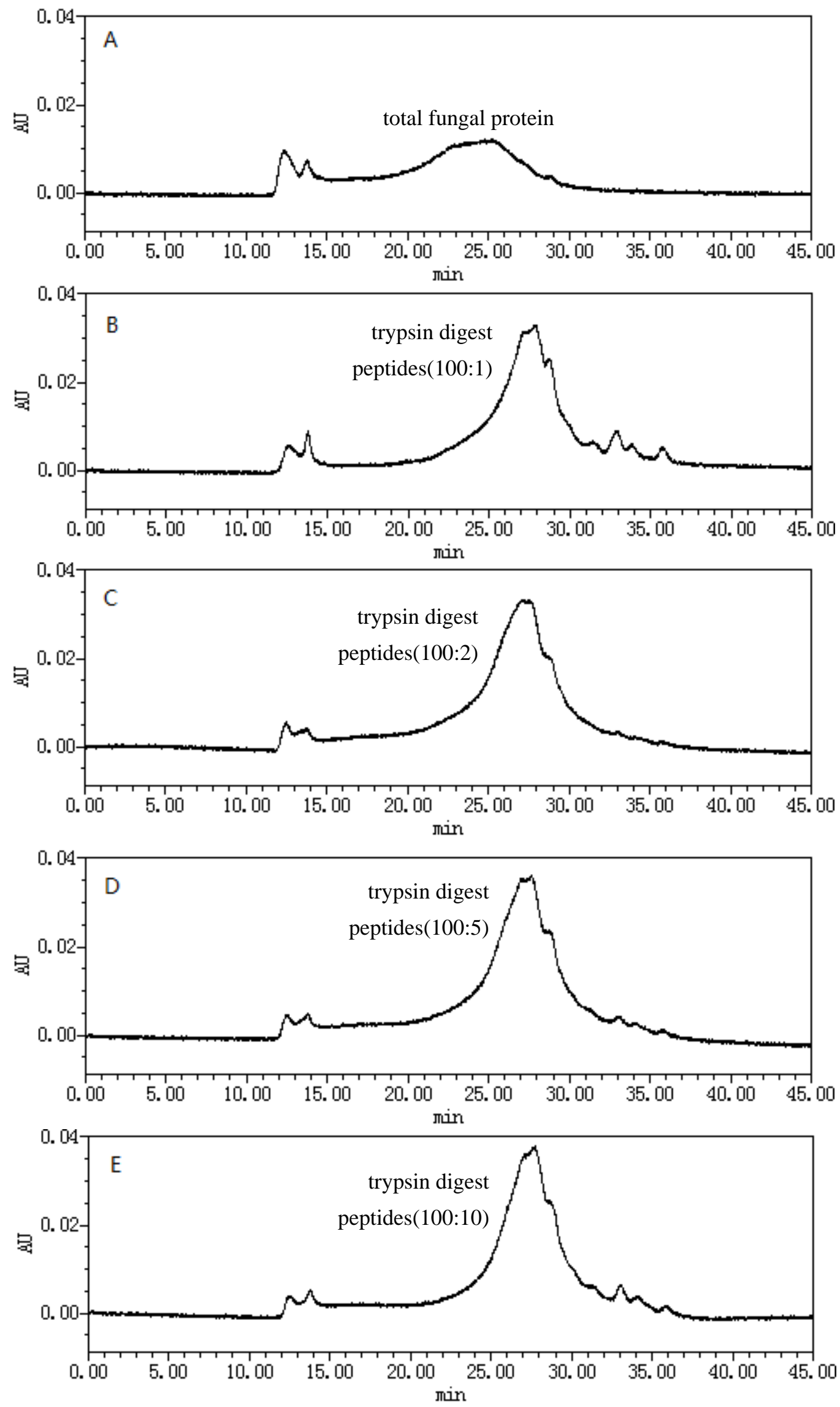

Figure 1. The gelfiltration chromatograms of (A) fungal protein from fermented $O$. sinensis mycelia powder and (B-E) therespective digest peptidesincubated at $37{ }^{\circ} \mathrm{C}$ for $18 \mathrm{~h}$ with sample-to-trypsin ratios of (B) 100:1; (C) 100:2; (D) 100:5; and (E) 100:10. 

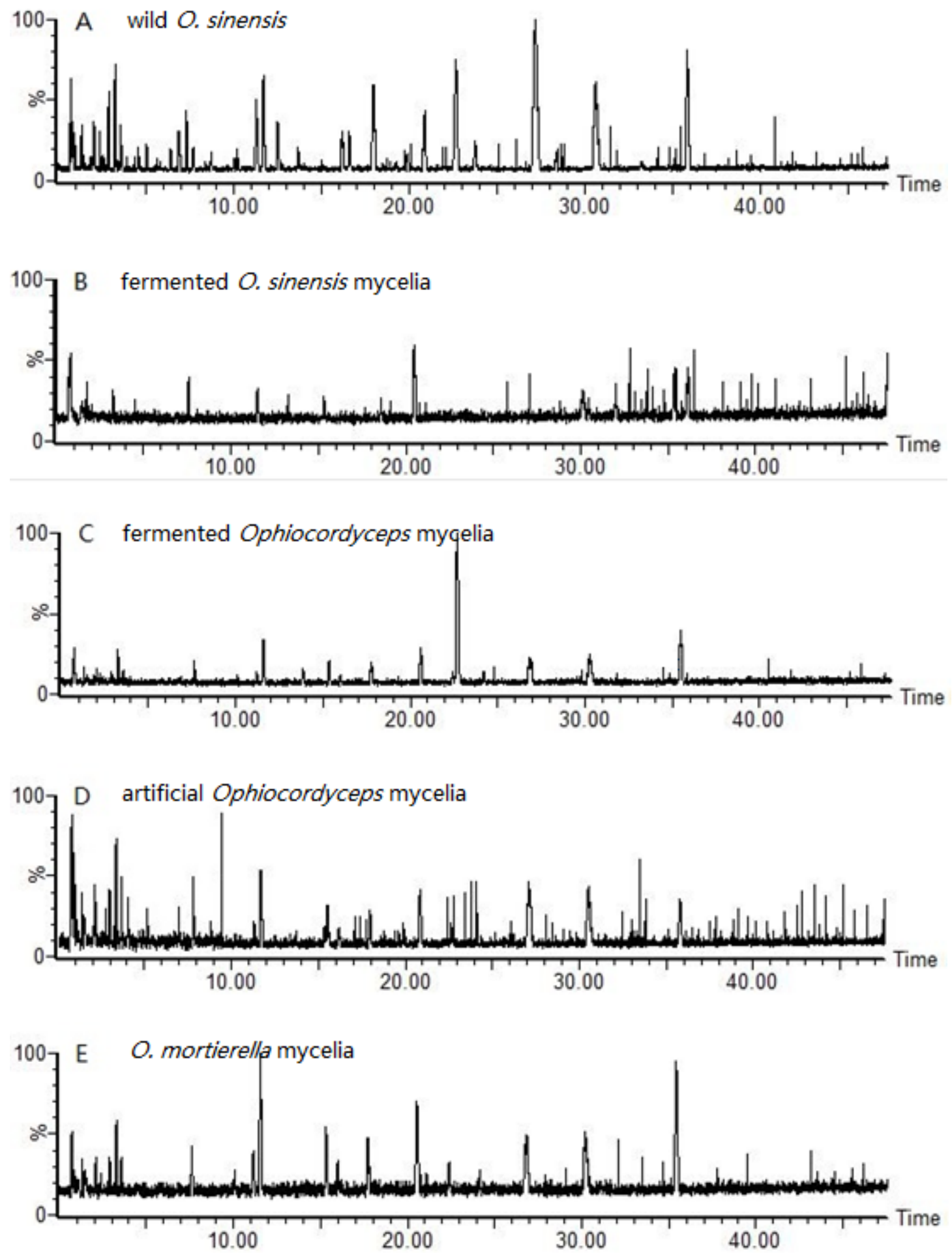

Figure 2. The positive-ion base-peak-intensity chromatograms of the digest peptides of: (A) wild O. sinensis fruiting body; (B) fermented O. sinensis mycelia powder; (C) fermented Ophiocordyceps mycelia powder; (D) artificial Ophiocordyceps mycelia powder; and (E) O. mortierella mycelia powder. 


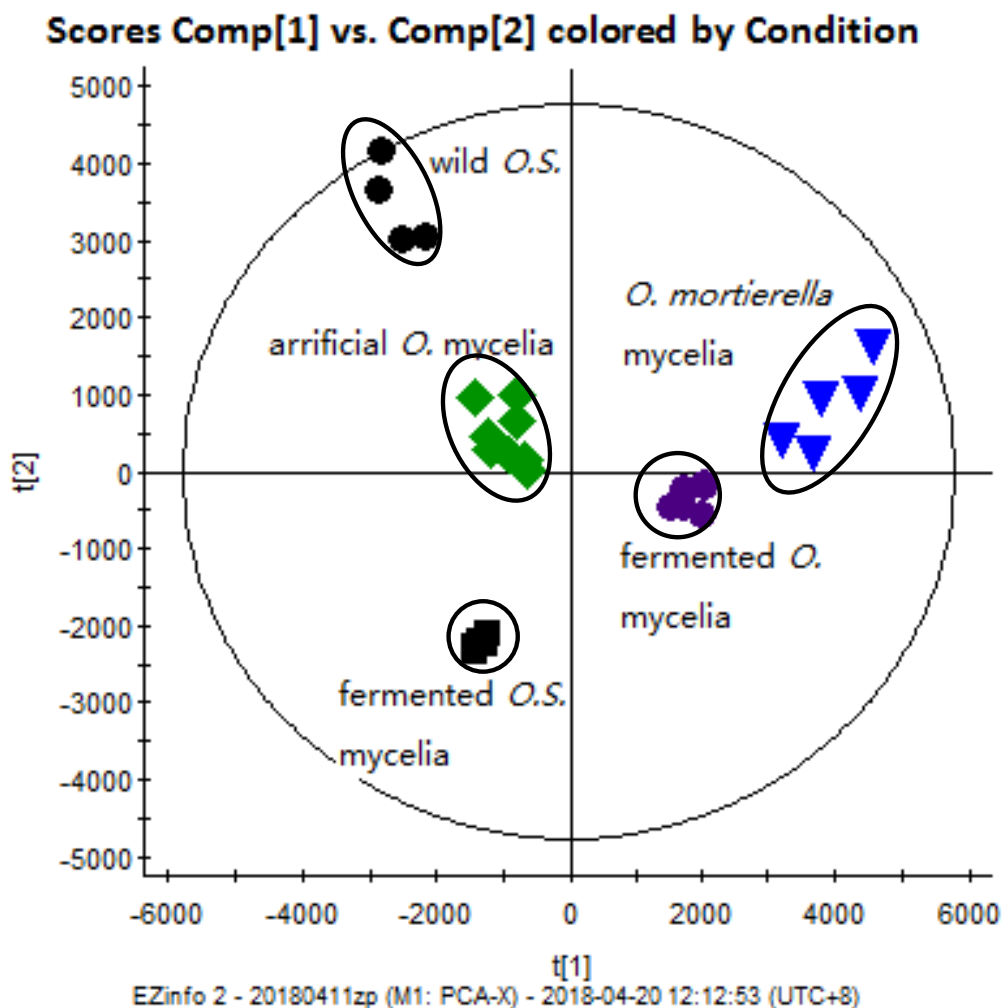

(a)

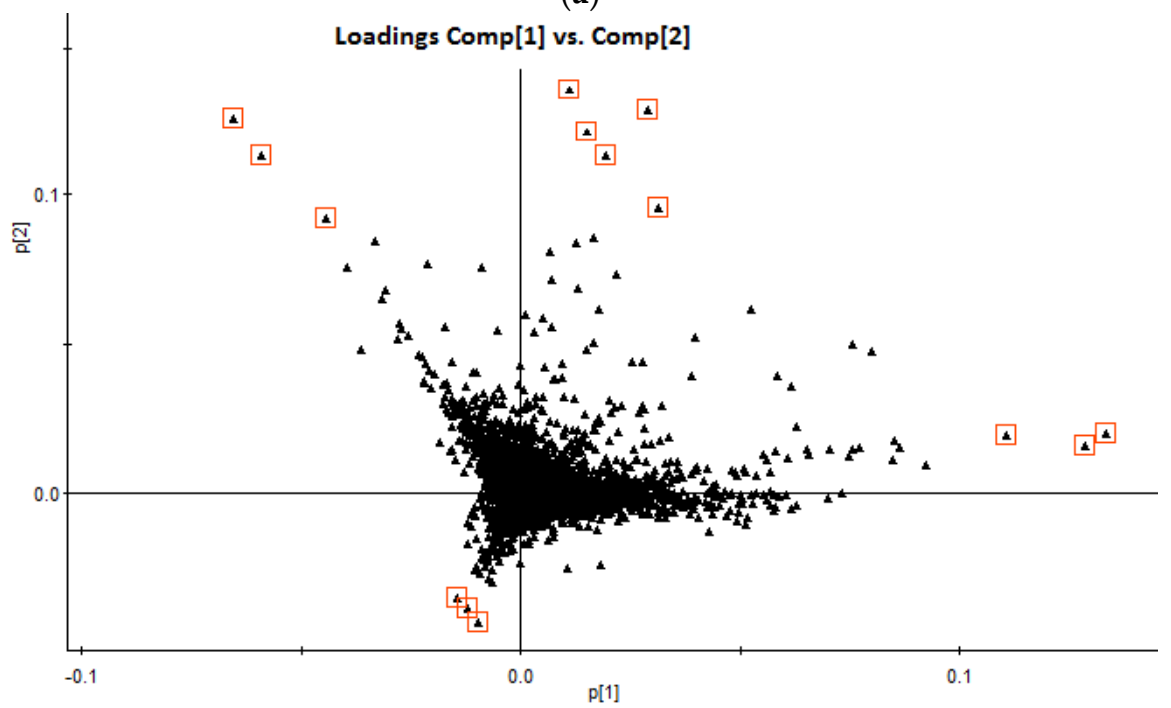

(b)

Figure 3. (a) The principal component analysis score plot of (1): wild O. sinensis fruiting body, $(\square)$ : fermented O.S. mycelia powder, $(\bullet)$ : artificial Ophiocordyceps mycelia powder, $(\bullet)$ : fermented Ophiocordyceps mycelia powder, $(\mathbf{\nabla})$ : O. mortierella mycelia powder, and (b) the loading plot of wild O. sinensis and four cultured Ophiocordyceps mycelia.

\subsection{Identification of Marker Peptides in Digested Mixtures}

The results from this study demonstrate that it is possible to isolate and identify marker peptides that play important roles in the authentication of various Ophiocordyceps mycelia. The loading plot from the PCA, based on the UPLC/MS data, is shown in Figure 3b. The ions that correspond to the EMRT pairs of 41.17-713.3967, 35.03-579.3498, 22.68-849.4741, 26.05-555.8072, and 13.60-414.7517 were chosen as marker peptides for each sample. The amino acid sequence of 
the marker peptides was determined using Mascot v2.5.1. Mascot was calibrated by searching the data on O. sinensis, Hirsutella sinensis, Paecilomyces hepialid, Gliocladium roseum, and Tolypocladium sinensis, which was obtained from the Universal Protein (UniProt) database. The Mascot search was performed with a fragment ion mass tolerance of $0.60 \mathrm{Da}$ and a parent ion tolerance of 15.0 ppm. Carbamidomethylated iodoacetamide (IAM) was specified in Mascot as a fixed modification, while oxidized dithiothreitol (DTT) was specified as a variable modification.

The results of the study showed that the ion with $m / z=713.3967$ was only found in the spectrum of the digested mixture of the wild O.S. fruiting body (Figure 4A). Moreover, extracted-ion mass spectrometry $\left(\mathrm{MS}^{\mathrm{E}}\right)$ revealed that this ion was doubly charged and that the MS/MS spectrum indicated that it corresponded to the TLLEAIDSIEPPK amino acid sequence. The partial LEAIDSIEPPK amino acid sequence was derived from the observed single charged y(11) $\mathrm{m} / \mathrm{z} 1211.6518$ ion, while the partial TL amino acid sequence was confirmed by the $b(2) m / z 215.1390$ ion. In contrast, the ion with $m / z=579.3498$ was only detected in the spectrum of the digested mixture of the fermented O.S. mycelia powder (Figure 4B). Similarly, the respective $\mathrm{MS}^{\mathrm{E}}$ spectrum revealed that this ion was doubly charged, while the MS/MS spectrum indicated that it corresponded to the AVLSDAITLV amino acid sequence. The partial AVL amino acid sequence was derived from the observed doubly charged $\mathrm{b}^{++}(3)$ $m / z 142.6021$ ion, while the partial SDAITLVR amino acid sequence was confirmed by the $\mathrm{y}(8) \mathrm{m} / \mathrm{z}$ 874.4993 ion. In addition, the ion with $m / z=849.4741$ was only found in the spectrum of the digested mixture of the fermented Ophiocordyceps mycelia powder (Figure $4 \mathrm{C}$ ). The $\mathrm{MS}^{\mathrm{E}}$ spectrum revealed that this ion was single charged, and that its MS/MS spectrum indicated that it corresponded to the FAELLEK amino acid sequence. The partial FAE amino acid sequence was derived from the observed single charged $b(3) m / z 348.1554$ ion, while the partial LLEK amino acid sequence was confirmed by the $y(4) m / z 502.3235$ ion. Moreover, the ion with $m / z=555.8072$ was only detected in the spectrum of the digested mixture of the artificial Ophiocordyceps mycelia powder (Figure 4D). The MS ${ }^{\mathrm{E}}$ spectrum revealed that this ion was doubly charged, and that its MS/MS spectrum indicated that it corresponded to the LESVVTSFTK amino acid sequence. The partial LESV amino acid sequence was derived from the observed doubly charged $\mathrm{b}^{++}(4) \mathrm{m} / \mathrm{z} 215.1208$ ion, while the partial VTSFTK amino acid sequence was confirmed by the $y(6) m / z 682.3770$ ion. Lastly, the ion with $m / z=414.7517$ was only found in the spectrum of the digested mixture of the O. mortierella mycelia powder (Figure $4 \mathrm{E}$ ). The corresponding $\mathrm{MS}^{\mathrm{E}}$ spectrum revealed that this ion was doubly charged, and that its MS/MS spectrum indicated that it corresponded to the VPSSAVLR amino acid sequence. The partial VPS amino acid sequence was derived from the observed doubly charged $b^{++}(3) m / z 142.5839$ ion, while the partial SAVLR amino acid sequence was confirmed by the $y(5) \mathrm{m} / \mathrm{z} 545.3406$ ion.

The amino acid sequences of the marker peptides of each Ophiocordyceps species were aligned using the Basic Local Alignment Search Tool (BLAST) of the UniProt database in order to identify the original protein types. The results were as follows: translation elongation factor 1- $\alpha$ (gi:A4U9H1), belonging to Ophiocordyceps brunneipunctata (Table 1) and recognized by Mascot matching as a precursor of the tryptic peptide TLLEAIDSIEPPK $(m / z 713.3967)$, was chosen as a marker of the wild O. sinensis fruiting body; linoleate diol synthase (gi: T5AC53), belonging to Hirsutella sinensis and recognized by Mascot matching as a precursor of tryptic peptide AVLSDAITLVR $(m / z$ 579.3498), was chosen as a marker for unambiguous identification of the fermented $O$. sinensis mycelia powder; the adenosine triphosphate (ATP) synthase subunit $\alpha$ (gi: A0A0B7JUZ6), belonging to Bionectria ochroleuca (Gliocladium roseum) and recognized by Mascot matching as a precursor of tryptic peptide LESVVTSFTK ( $m / z$ 555.8072), was chosen as a marker of the artificial Ophiocordyceps mycelia powder(Gliocladium roseum species). However, the two ions at $m / z 849.4741$ and 414.7517 were not assigned to any protein by the Mascot matching. The selected ion monitoring chromatograms of the marker peptides and the corresponding spectra $\left(\mathrm{MS}^{\mathrm{E}}\right)$ are shown in Figure 4. In most cases, the amino acid sequences were recognized to belong to specific proteins of the analyzed species, while in other cases, the peptide was not assigned to any protein, with the engine indicating only partial matching (in brackets, Table 1). 
Table 1. The multianalyte results of the marker peptides from Ophiocordyceps sinensis and the four cultured O. mycelia.

\begin{tabular}{|c|c|c|c|c|c|c|c|c|}
\hline \multirow[b]{2}{*}{ Item } & \multirow[b]{2}{*}{ No.of Ions } & \multicolumn{4}{|c|}{ Marker } & \multicolumn{3}{|c|}{ Mascot Matching } \\
\hline & & $\begin{array}{c}\text { Precursor Ion, } \\
(m / z)\end{array}$ & Charge & $\begin{array}{c}\text { Fragment Ion, } \\
(\mathrm{m} / \mathrm{z})\end{array}$ & Time, (min) & Peptide Match & $\begin{array}{c}\text { Peptide } \\
\text { Fragmentation }\end{array}$ & Protein Match \\
\hline \multirow{13}{*}{$\begin{array}{l}\text { Ophiocordyceps } \\
\text { sinensis }\end{array}$} & 1 & 713.39 & 2 & & 41.1 & \multicolumn{2}{|l|}{ TLLEAIDSIEPPK } & \multirow{7}{*}{$\begin{array}{c}\text { gi:A4U9H1 } \\
\text { (Ophiocordyceps } \\
\text { brunneipunctata) }\end{array}$} \\
\hline & \multirow{12}{*}{2} & \multirow{12}{*}{851.74} & & 969.52 & \multirow{12}{*}{46.2} & & $\mathrm{y}$ & \\
\hline & & & & 898.48 & & & $\mathrm{y}$ & \\
\hline & & & & 785.4 & & & $\mathrm{y}$ & \\
\hline & & & & 215.13 & & & $\mathrm{~b}$ & \\
\hline & & & & 452.25 & & & $y^{0}$ & \\
\hline & & & & 881.46 & & & $y^{*}$ & \\
\hline & & & 3 & & & SVEMHHEQLTEGL & LPGDNVGFNVK & gi: 0A060IK44 \\
\hline & & & & 1046.52 & & & $\mathrm{y}$ & $\begin{array}{l}\text { (Ophiocordyceps } \\
\text { sinensis) }\end{array}$ \\
\hline & & & & 949.47 & & & $\mathrm{y}$ & \\
\hline & & & & 497.7 & & & $\mathrm{~b}++$ & \\
\hline & & & & 596.25 & & & $b^{*}++$ & \\
\hline & & & & $\begin{array}{c}777.42 \\
1208.54\end{array}$ & & & $\begin{array}{l}\mathrm{y} \\
\mathrm{b}\end{array}$ & \\
\hline \multirow{19}{*}{$\begin{array}{l}\text { fermented } O \text {. } \\
\text { sinensis mycelia }\end{array}$} & \multirow[t]{7}{*}{3} & \multirow[t]{7}{*}{579.34} & 2 & & \multirow[t]{7}{*}{35} & AVLSDAITLVR & & \multirow{7}{*}{$\begin{array}{l}\text { gi: T5AC53 } \\
\text { (Hirsutella } \\
\text { sinensis) }\end{array}$} \\
\hline & & & & 987.58 & & & $\mathrm{y}$ & \\
\hline & & & & 874.49 & & & $\mathrm{y}$ & \\
\hline & & & & 787.46 & & & $\mathrm{y}$ & \\
\hline & & & & 672.44 & & & $\mathrm{y}$ & \\
\hline & & & & 488.31 & & & $\mathrm{y}$ & \\
\hline & & & & 142.6 & & & $b++$ & \\
\hline & \multirow[t]{6}{*}{4} & \multirow[t]{6}{*}{670.3} & 2 & & \multirow[t]{6}{*}{14.5} & \multirow[t]{6}{*}{ NAGSGCPTYTVGR } & & \multirow{6}{*}{$\begin{array}{l}\text { gi: T5AC53 } \\
\text { (Hirsutella } \\
\text { sinensis) }\end{array}$} \\
\hline & & & & 1154.52 & & & $\mathrm{y}$ & \\
\hline & & & & 1010.47 & & & $\mathrm{y}$ & \\
\hline & & & & 397.21 & & & $y++$ & \\
\hline & & & & 370.13 & & & $b^{*}$ & \\
\hline & & & & 387.16 & & & $\mathrm{~b}$ & \\
\hline & \multirow[t]{6}{*}{5} & \multirow[t]{6}{*}{614.85} & 2 & & \multirow[t]{6}{*}{54.7} & MVEVLGIIQAR & & \multirow{6}{*}{$\begin{array}{l}\text { gi: T5AC53 } \\
\text { (Hirsutella } \\
\text { sinensis) }\end{array}$} \\
\hline & & & & 657.4 & & & $\mathrm{y}$ & \\
\hline & & & & 770.48 & & & $\mathrm{y}$ & \\
\hline & & & & 998.59 & & & $\mathrm{y}$ & \\
\hline & & & & 231.11 & & & $\mathrm{~b}$ & \\
\hline & & & & 360.15 & & & $\mathrm{~b}$ & \\
\hline
\end{tabular}


Table 1. Cont.

\begin{tabular}{|c|c|c|c|c|c|c|c|c|}
\hline & \multirow[b]{2}{*}{6} & \multicolumn{4}{|c|}{ Marker } & \multicolumn{3}{|c|}{ Mascot Matching } \\
\hline \multirow{12}{*}{$\begin{array}{c}\text { artificial } \\
\text { Ophiocordyceps } \\
\text { mycelia }\end{array}$} & & 555.8 & 2 & & 26 & LESVVTSFTK & & gi: 0A0B7JUZ6 \\
\hline & & & & 868.47 & & & $\mathrm{y}$ & $\begin{array}{l}\text { (Gliocladium } \\
\text { roseum) }\end{array}$ \\
\hline & & & & 682.37 & & & $\mathrm{y}$ & \\
\hline & & & & 243.13 & & & $\mathrm{~b}$ & \\
\hline & & & & 215.12 & & & $\mathrm{~b}++$ & \\
\hline & 7 & 63734 & 2 & 482.75 & & & $\mathrm{~b}++$ & \\
\hline & 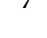 & 038.04 & 2 & & 44.9 & HALVIYDDLSK & & $\begin{array}{l}\text { gi: 0A0B7JUZ6 } \\
\text { (Glitcladium }\end{array}$ \\
\hline & & & & 952.49 & & & $\mathrm{y}$ & roseum) \\
\hline & & & & 740.34 & & & $\mathrm{y}$ & \\
\hline & & & & 577.28 & & & $\mathrm{y}$ & \\
\hline & & & & 209.1 & & & $\mathrm{~b}$ & \\
\hline & & & & 534.33 & & & $\mathrm{~b}$ & \\
\hline \multirow{9}{*}{$\begin{array}{c}\text { fermented } \\
\text { Ophiocordyceps } \\
\text { mycelia }\end{array}$} & 8 & 849.47 & 1 & & 22.6 & (FAELLEK) & & Unassigned \\
\hline & & & & 502.32 & & & $\mathrm{y}$ & \\
\hline & & & & 389.23 & & & $\mathrm{y}$ & \\
\hline & & & & 348.15 & & & $\mathrm{~b}$ & \\
\hline & 9 & 799.44 & 2 & 966.52 & 58 & YLEIIKETSNFIK & $\mathrm{y}$ & $\begin{array}{c}\text { gi: } \\
\text { A0A172PXZ9 }\end{array}$ \\
\hline & & & & 596.85 & & & $\mathrm{y}^{++}$ & $\begin{array}{c}\text { (Ophiostoma } \\
\text { pseudocatenulatum) }\end{array}$ \\
\hline & & & & 406.19 & & & $\mathrm{~b}$ & \\
\hline & & & & 990.55 & & & $\mathrm{~b}$ & \\
\hline & & & & 487.26 & & & $b^{*++}$ & \\
\hline \multirow{4}{*}{$\begin{array}{l}\text { O. mortierella } \\
\text { mycelia }\end{array}$} & 10 & 414.75 & 2 & & 13.6 & (VPSSAVLR) & & Unassigned \\
\hline & & & & 458.3 & & & $\mathrm{y}$ & \\
\hline & & & & 370.24 & & & $\mathrm{y}^{*}$ & \\
\hline & & & & $\begin{array}{l}387.27 \\
142.58\end{array}$ & & & $\mathrm{y}$ & \\
\hline
\end{tabular}

Note: $\mathbf{y} *(m / z=881.46)$ ion was dehydroxylated ion of $\mathbf{y}(m / z=898.48) ; \mathbf{b}^{*++}(m / z=596.25)$ ion was dehydroxylated ion of $\mathbf{b}(m / z=1208.54)$ with two charges, $\mathbf{b}^{*}(m / z=370.13)$ ion was dehydroxylated ion of $\mathbf{b}(m / z=387.16), \mathbf{b}^{*}++(m / z=487.26)$ ion was dehydroxylated ion of $\mathbf{b}(m / z=990.55)$ with two charges, and $\mathbf{y} *(m / z=370.24)$ ion was dehydroxylated ion of $\mathrm{y}(m / z=387.27)$. 

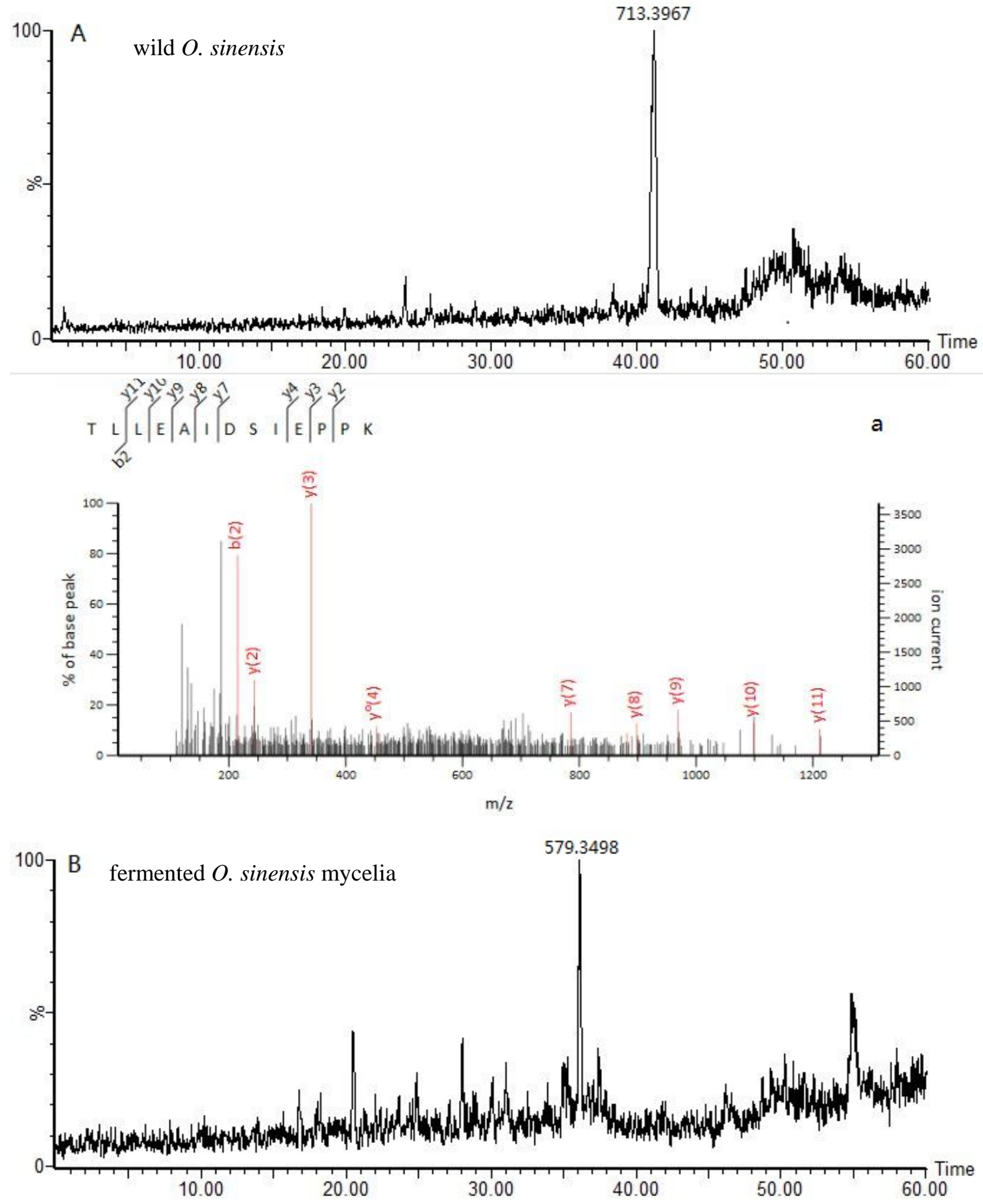

Figure 4. Cont. 

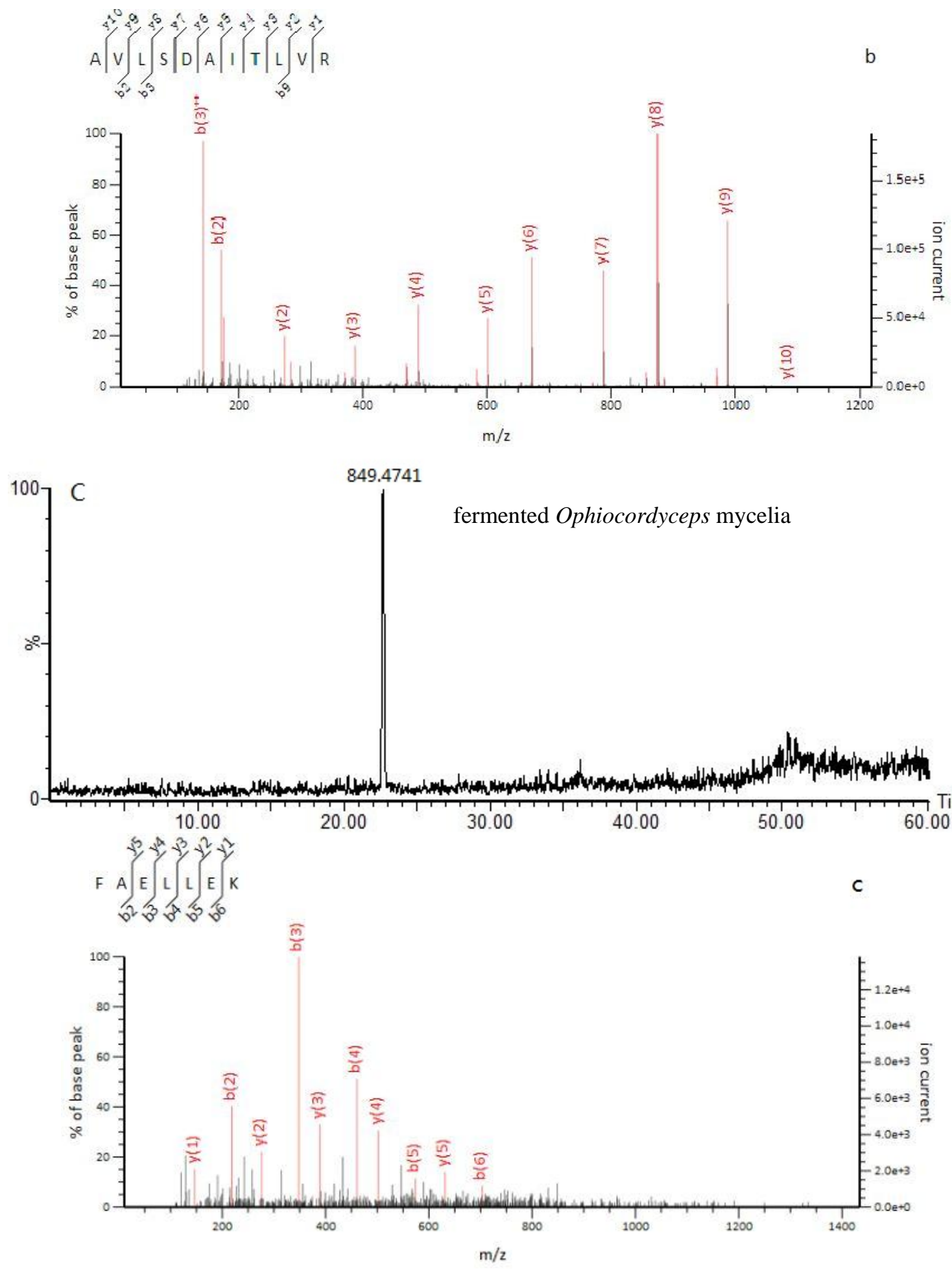

Figure 4. Cont. 

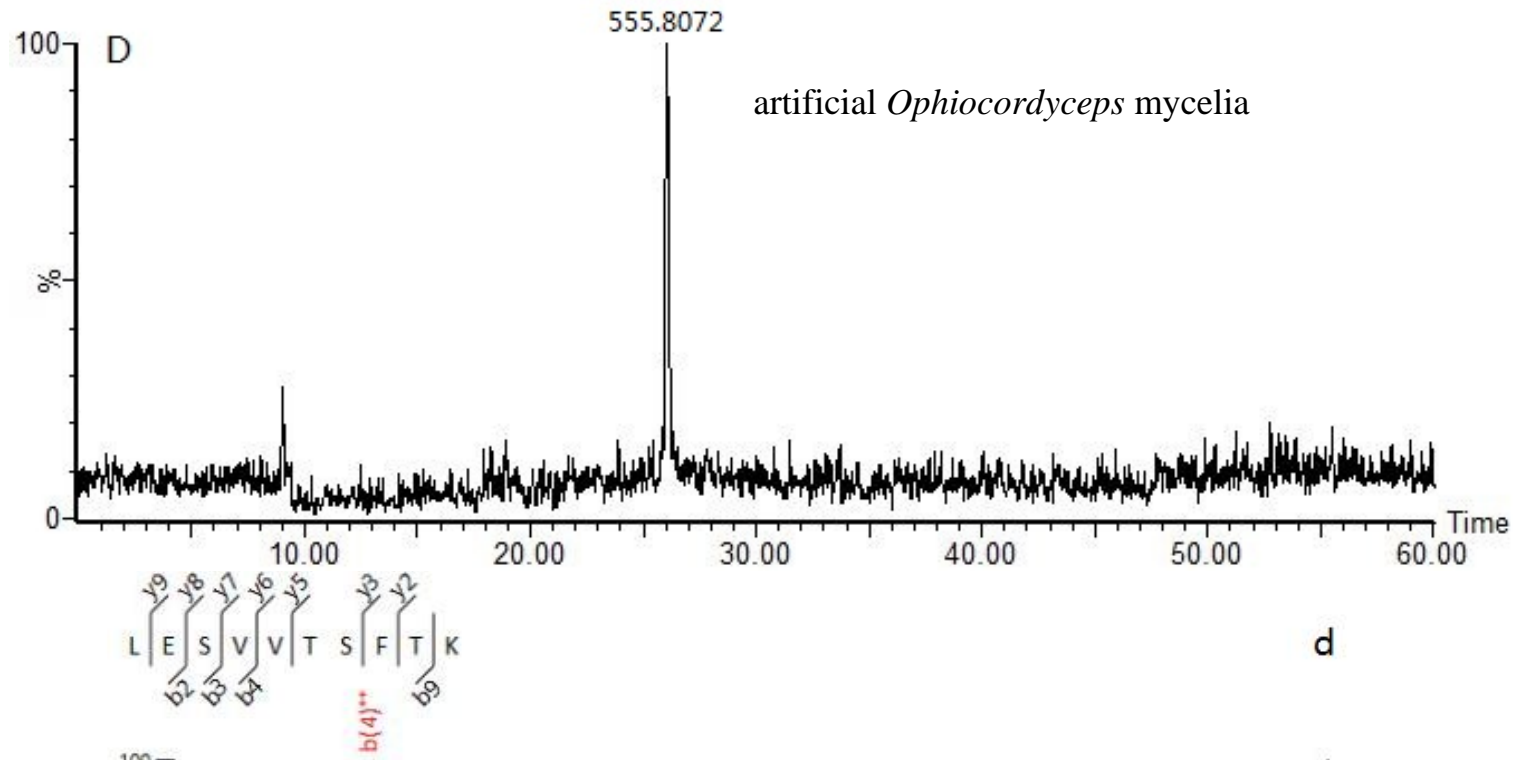

d
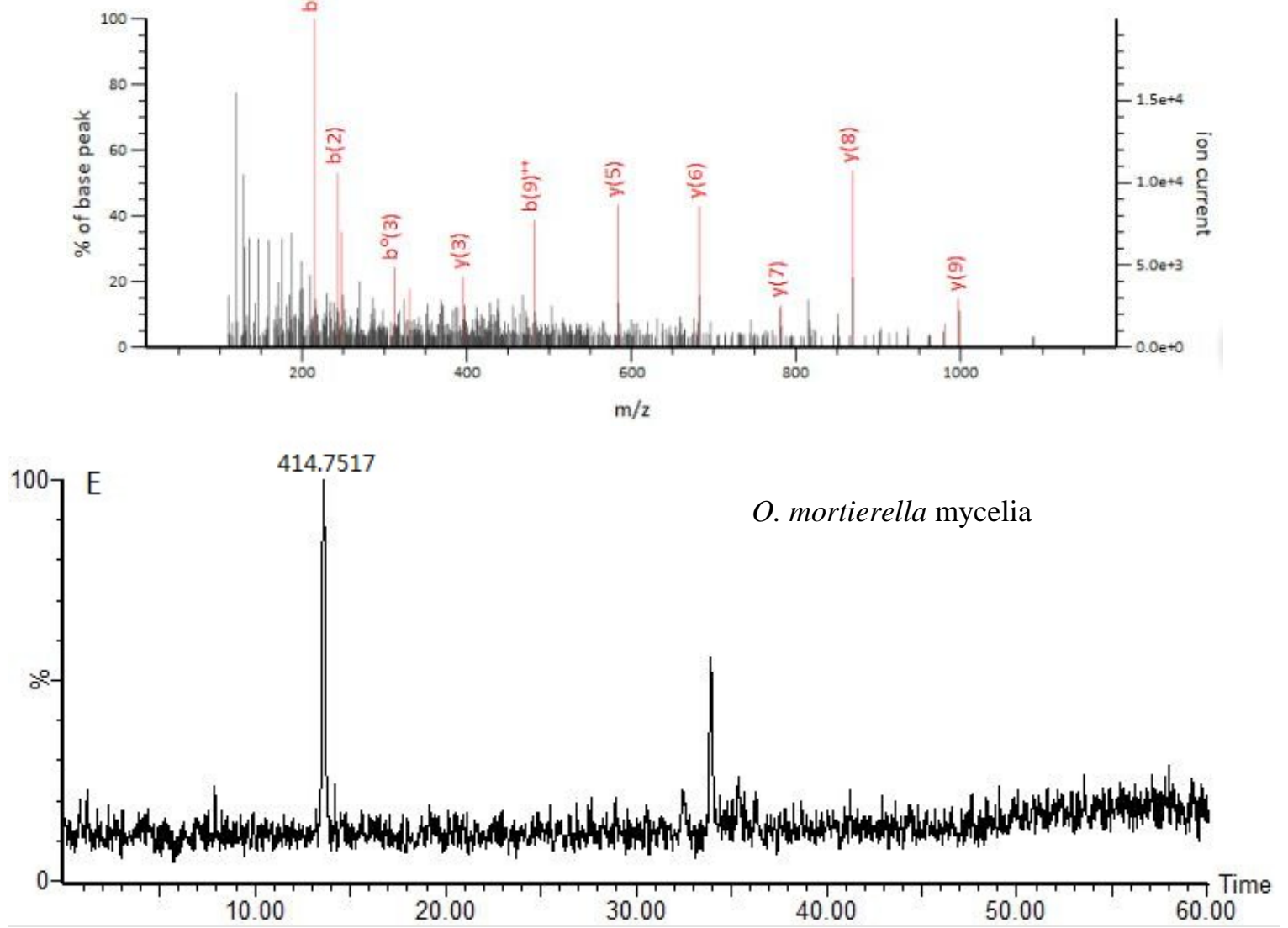

Figure 4. Cont. 


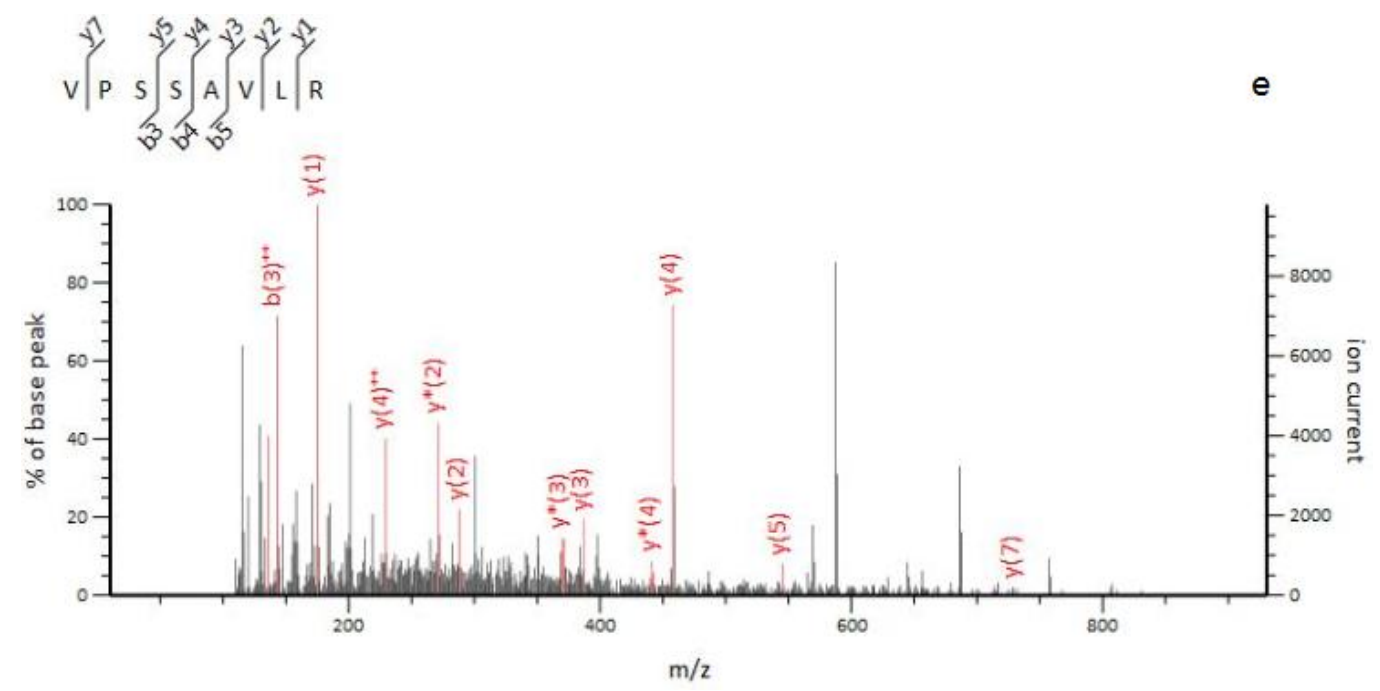

Figure 4. The selected ion-monitoring chromatograms of marker peptides in (A) wild $O$. sinensis fruiting body, $m / z$ 713.39, a doubly charged TLLEAIDSIEPPK fragment ion; (B) fermented O. sinensis mycelia powder, $m / z$ 579.34, a doubly charged AVLSDAITLVR fragment ion; (C) fermented Ophiocordyceps mycelia powder, $m / z$ 849.47, a singly charged FAELLEK fragment ion; (D) artificial Ophiocordyceps mycelia powder, $m / z 555.80$, a doubly charged LESVVTSFTK fragment ion; and (E) O. mortierella mycelia powder, $m / z 414.75$, a doubly charged VPSSAVLR fragment ion. Correspondingly, the fragment ion mass spectrogram of marker peptides in (a) wild O. sinensis fruiting body; (b) fermented O. sinensis mycelia powder; (c) fermented Ophiocordyceps mycelia powder; (d) artificial Ophiocordyceps mycelia powder; and (e) O. mortierella mycelia powder.

\section{Discussion}

Due to its apparent beneficial clinical and health effects, O. sinensis has been employed in China as a highly valued traditional Chinese medicine for centuries. Recently, it has become increasingly popular and is now widely used, especially by elderly and unhealthy people in China and abroad, as a dietary supplement or natural remedy [25,48]. However, the market price for $O$. sinensis has increased remarkably due to insufficient resources and growing demand. Moreover, other Ophiocordyceps-related fungi and the conidial form of the artificially cultured O. sinensis fermentation mycelia have also been used as substitutes in Chinese medicine and healthy foods [11,12], thereby causing confusion in the market management and challenging the safe use of $O$. sinensis. Therefore, it is crucial to develop a reliable and practical method to differentiate $O$. sinensis from its substitutes, especially the cultured mycelia.

In this study, the marker peptides in the digest mixtures of fungal proteins were determined by UPLC/MS/MS coupled with chemometrics using wild O.S. fruiting bodies and several commercially available mycelium fermented powders. Moreover, the marker peptides were detected, and the amino acid sequences of the marker peptides were identified. The obtained results showed that the marker peptides could provide accurate species identification for the Ophiocordyceps samples by biological mass spectrometry. To the best of our knowledge, the first extensive study on the authentication of O. sinensis and revelent-cultured Ophiocordyceps mycelia by biological mass spectrometry combined with chemometrics, thereby provided a powerful quality control tool.

Previous studies report different macroscopic and microscopic methods that can be used to identify O. sinensis-related products [23,26-29]. Nevertheless, the probability of the accurate identification of the species level was not the same for the different species [32,49-52]. Most studies focused on morphological characterizations, microscopy studies, determination of the chemical composition, and PCR amplifications. However, none of them analyzed the specific fungal protein or, more specifically, the marker peptide that identifies the species level of $O$. sinensis. 
The fungal protein is a special protein that is differentiated by the type of fungus [40]. One efficient method for proteomic analysis is biological mass spectrometry [39,53,54]. In recent years, many studies have focused on the fungal proteins. Two dimensional electrophoresis (2-DE) and sodium dodecyl sulfate-polyacrylamide gel electrophoresis (SDS-PAGE) was used to examine and identify $O$. sinensis $[40,55]$. Then, five proteins were identified using MALDI-TOF-TOF/MS. Based on the proteomic profile of $O$. sinensis, 2-DE identification pattern was provided, and this approach was a foundation for intensive study of $O$. sinensis proteins. Another isobaric tag for relative and absolute quantification (i TRAQ)-coupled two-dimensional liquid chromatography tandem mass spectrometry(2D LC-MS/MS) proteomics approach was used to analyze the protein profiles of samples of the larva and various development stages of Chinese Cordyceps. This bioinformatics analysis revealed that i TRAQ-coupled 2D LC-MS/MS was a unique method for identifying protein groups of Chinese Cordyceps at different development stages [56]. None of these methods can effectively identify and distinguish Ophiocordyceps sinensis and its revelent-fermented Ophiocordyceps mycelia. In this study, we employed this approach to identify the marker peptides of the specific fungal proteins in wild $O$. sinensis and four revelent-fermented Ophiocordyceps mycelia powders. Then, as a result, TLLEAIDSIEPPK $(m / z$ 713.39) was detected in wild $O$. sinensis fruiting bodies, which was matched to protein of translation elongation factor $1-\alpha$, belonging to Ophiocordyceps brunneipunctata. $\operatorname{AVLSDAITLVR~}(m / z$ 579.34) was discovered in the fermented O. sinensis mycelium powder, which was matched to protein of linoleate diol synthase, belonging to Hirsutella sinensis. FAELLEK $(m / z$ 849.47) was found in fermented $O$. mycelium powder, which was not matched to any protein. LESVVTSFTK $(m / z 555.80)$ was identified in artificial $O$. mycelium powder, which was matched to protein of ATP synthase subunit $\alpha$, belonging to Gliocladium roseum. VPSSAVLR $(m / z 414.75)$ was detected in O. mortierella mycelium powder, which was not matched to any protein. All in all, three marker peptides were matched to the corresponding species; two marker peptides were not matched to corresponding species, but they were specific peptides.

In order to verify their specificity, all marker peptides were synthesized and tested on the samples. The results from the measurements of the aforementioned five samples revealed the following information on the marker peptides: TLLEAIDSIEPPK was only present in wild O. sinensis, AVLSDAITLVR was only detected in fermented O. sinensis mycelium powder, FAELLEK was only observed in fermented Ophiocordyceps mycelium powder, LESVVTSFTK was only present in artificial $O$. mycelium powder, and VPSSAVLR was only found in O. mortierella mycelium powder. Previous studies revealed the proteins from 26 different producing areas were obviously different in the numbers and abundance of protein spots of protein profiles, and this showed certain association with producing areas [40]. Another report revealed five proteins of $O$. sinensis were identified in 2-DE, but the specific protein was not reported [55]. Isobaric tags for relative and absolute quantification (i TRAQ)-coupled two-dimensional liquid chromatography tandem mass spectrometry (2D LC-MS/MS) proteomics approach was used to analyze the protein profiles of samples of the larva and various development stages of Chinese Cordyceps. The results indicated that protein composition of mummified larva, sclerotium, and stroma were significantly different from commercial cordyceps [56]. These were the results of studying the producing area and various development stages of $O$. sinensis. Few study results of the differential proteins of $O$. sinensis and various cultured Ophiocordyceps mycelia were reported. In our study, the specific marker peptides were found by chemomatrics first and identified the sequence using MASCOT. Thus, we could examine the marker peptides to identify the $O$. sinensis and revelent-fermented Ophiocordyceps mycelia products.

The method developed in this study could be applied not only to qualitatively identify the O. sinensis-related species, but also to quantitatively determine the contents of the marker peptides to control the qualityof the Ophiocordyceps related products. Moreover, the biological mass spectrometry method is also suitable for the identification of Chinese medicinal materials derived from animals, especially processed animal medicinal materials such as Cicadae periostracum, processed Manis squama, etc. However, because Chinese herbal medicine contains many complex ingredients, the extraction 
of high-purity and high-quality protein components is a key requirement of this method and its application to traditional Chinese medicine (TCM).

\section{Materials and Methods}

\subsection{Materials and Reagents}

Polyacrylamide and Coomassie Brilliant Blue were purchased from Sigma-Aldrich (St. Louis, MO, USA). Acetic acid was purchased from Beijing Chemical Reagent Co. (Beijing, China), while dithiothreitol (DTT), iodoacetamide (IAM), and trifluoroacetic acid (TFA) were purchased from Sigma-Aldrich (St. Louis, MO, USA). The reagents used were either of chemical or analytical reagent grade. Ammonium hydrogen carbonate (analytical reagent grade) was purchased from Beijing Chemical Reagent Co. (Beijing, China); formic acid was obtained from Sigma-Aldrich (St. Louis, MO, USA); and acetonitrile (HPLC grade) was purchased from Fisher Scientific (Fair Lawn, NJ, USA). The ultra-high-purity water was prepared using a Milli-Q water purification system (Millipore Corporation, Bedford, MA, USA). Trypsin (sequencing grade) was obtained from Pierce (Thermo Scientific, Waltham, MA, USA). The syringe filters (diameter: $0.22 \mu \mathrm{m}$ ) were purchased from Millipore (Billerica, MA, USA). Four wild O.S. samples were collected from the Tibetan province in China. The sources were identified by Chief Pharmacist Zhang nan-ping of National Institutes for Food and Drug Control (NIFDC) in China. Five fermented O. sinensis mycelia samples were provided by Hangzhou Sino-US Huadong Pharmaceutical Co., Ltd. (Hangzhou, China), and six fermented Ophiocordyceps mycelia samples were obtained from Jiangxi Jiminkexin Pharmaceutical Co. Ltd. (Nanchang, China). Eight artificial Ophiocordyceps mycelia samples were provided by Hebei Chang Tian Pharmaceutical Co., Ltd. (Shijiazhuang, China), and five O. mortierella mycelia samples were obtained from Zhejiang Changxing Pharmaceutical Co. Ltd. (Hangzhou, China) (Table 2). These strains of four fermented Ophiocordyceps mycelia were identified by Institute of Microbiology, Chinese Academy of Sciences in China.

Table 2. The Ophiocordyceps-related samples' information included in this study.

\begin{tabular}{cccc}
\hline Sample Status & Claimed Names $^{\text {a }}$ & No. of Samples & Locations \\
\hline Wild fruiting body & Ophiocordyceps sinensis & 4 & Tibet \\
\hline $\begin{array}{c}\text { Cultured mycelium } \\
\text { powder }\end{array}$ & Fermented O.S. mycelia & 5 & Zhejiang \\
& Fermented Ophiocordyceps mycelia & 6 & Jiangxi \\
\hline & Artificial Ophiocordyceps mycelia & 8 & Hebei \\
O. mortierella mycelia & 5 & Zhejiang \\
\hline
\end{tabular}

a Sample names when they were collected; ${ }^{b}$ cultured mycelium powder was collected from the manufacturing enterprise of each sample.

\subsection{Extraction of Ophiocordyceps Fungal Proteins}

First, deionized water $(0.5 \mathrm{~mL})$ was added to a collected sample $(10 \mathrm{mg})$ in a $1.5-\mathrm{mL}$ microfuge tube. The sample was mixed, centrifuged for $5 \mathrm{~min}$ at 20,000 $\times g$, and the supernatant was completely removed. Subsequently, a lysis buffer $(30 \mu \mathrm{L})$ and silica powder $(\Phi 0.5 \mathrm{~mm})$ were added to the tube, and its contents were ground repeatedly with a plastic pestle for $2 \mathrm{~min}$ using twisting motions. Next, lysis buffer $(150 \mu \mathrm{L})$ was added, and the sample was ground again for $30 \mathrm{~s}$ with the same pestle. The tube was centrifuged for $5 \mathrm{~min}$ at $14,000 \times g$, the supernatant was collected in a new tube, and another aliquot of a lysis buffer $(150 \mu \mathrm{L})$ was added to the prime tube. The sample was ground again for $30 \mathrm{~s}$ with the same pestle, and the tube was centrifuged for $5 \mathrm{~min}$ at $14,000 \times \mathrm{g}$. The supernatant was collected and transferred to a Millipore $3 \mathrm{~K}$ ultrafiltration spin column placed in a 2-mL collection tube. The spin column was centrifuged for $25 \mathrm{~min}$ at $12,000 \times \mathrm{g}$, after which the filtrate was discarded and $\mathrm{NH}_{4} \mathrm{HCO}_{3}(300 \mu \mathrm{L}, 0.05 \mathrm{~mol} / \mathrm{L}, \mathrm{pH} 8.0)$ was added. The spin column was centrifuged for $25 \mathrm{~min}$ at $12,000 \times \mathrm{g}$, and the filtrate was discarded again. This step was repeated twice 
before the spin column was inverted into a new2-mL collection tube and centrifuged for $5 \mathrm{~min}$ at $14,000 \times g$. Finally, another aliquot of $\mathrm{NH}_{4} \mathrm{HCO}_{3}(300 \mu \mathrm{L}, 0.05 \mathrm{~mol} / \mathrm{L}, \mathrm{pH} 8.0)$ was added, and the sample was diluted to a concentration of $1 \mathrm{mg} / \mathrm{mL}$ [57-59].

\subsection{Purification and Tryptic Digestion}

Each protein solution $(100 \mu \mathrm{L})$ was purified by polyacrylamide gel electrophoresis with a $16 \%$ polyacrylamide concentrate gel at $100 \mathrm{~V}$ for $10 \mathrm{~min}$. The protein gel was stained with Coomassie Brilliant Blue for $2 \mathrm{~h}$ and then decolorized with acetic acid for $2 \mathrm{~h}$. The blue bands were cut into small pieces and rinsed three times with water. Subsequently, DTT $(10 \mathrm{mM})$ was added to the gel pieces at $56{ }^{\circ} \mathrm{C}$, and the mixture was incubated for $45 \mathrm{~min}$. After this, the solution was removed, and iodoacetamide $(55 \mathrm{mM})$ was added to the gel. The reaction was left to proceed for $30 \mathrm{~min}$ at room temperature in the dark. Next, the $\mathrm{NH}_{4} \mathrm{HCO}_{3}(0.05 \mathrm{M}) / \mathrm{ACN}(1: 1, v / v)$ solution $(20 \mathrm{~mL})$ was used to decolorize the gel, and then, the decolorizing agent was added twice every $30 \mathrm{~min}$. The gel pieces were dehydrated rapidly with acetonitrile and vacuum-dried for $30 \mathrm{~min}$. A trypsin $/ 0.05 \mathrm{M}$ $\mathrm{NH}_{4} \mathrm{HCO}_{3}$ solution $(1: 20, v / v)$ was employed to digest the proteins in the gel. Each mixture was incubated at $37^{\circ} \mathrm{C}$ for $18 \mathrm{~h}$, and then eachsolution was transferred into a new 2-mL tube. The gel pieces were incubated at $37^{\circ} \mathrm{C}$ overnight after adding $\mathrm{ACN} / \mathrm{H}_{2} \mathrm{O}(1: 1, v / v$, containing $5 \% \mathrm{TFA})$. Subsequently, the solution was collected and dried using a vacuum centrifugal concentrator. The residue was dissolved in aqueous formic acid (0.1\%) and analyzed by UPLC/Orbitrap Fusion MS/MS [60-62].

\subsection{Size Exclusion Chromatography of the Digest Mixture}

The molecular weight ranges of the digest mixtures were determined on a TSK G2000SWL column (7.8 $\mathrm{mm}$ id $\times 300 \mathrm{~mm}$ length; particle size, $5 \mu \mathrm{m}$ ) (Tosoh Bioscience, Tokyo, Japan) using a Waters 2695-2998 liquid chromatography system (Waters Instruments Co., Rochester, MN, USA). The mobile phase was comprised of a phosphate buffer $(0.02 \mathrm{~mol} / \mathrm{L})$ containing sodium sulfate $(0.1 \mathrm{~mol} / \mathrm{L})$. The flow rate was set to $0.5 \mathrm{~mL} / \mathrm{min}$. A $10-\mu \mathrm{L}$ aliquot of the sample was withdrawn from the digest mixture and injected directly onto the column. The UV detection was recorded at $220 \mathrm{~nm}$. The size exclusion chromatography results are displayed in Figure 1.

\subsection{Chromatographic Separation and Mass Spectrometry}

The liquid chromatography (LC) separation was conducted using a Thermo Scientific ${ }^{\mathrm{TM}}$ EASY-nLC ${ }^{\text {TM }} 1000$ HPLC system (Thermo Fisher Scientific Inc., Waltham, MA, USA). The mobile phases were composed of (A)water (with $0.1 \%$ of formic acid) and (B)acetonitrile (with $0.1 \%$ of formic acid). The peptides were loaded directly onto a homemade C18 column $(75 \mu \mathrm{m}$ id $\times 15 \mathrm{~cm}$, $3 \mu \mathrm{m}, 120 \AA$ A). The analytical mobile phase gradient was $2-6 \%$ B from $0-1 \mathrm{~min}, 6-25 \%$ B from $1-46 \mathrm{~min}$, $25-35 \%$ B from $46-61 \mathrm{~min}, 35-80 \%$ B from $61-62 \mathrm{~min}$, and finally $80 \%$ B for an additional $8 \mathrm{~min}$. The flow rate was set to $300 \mathrm{~nL} / \mathrm{min}$ for these analytical gradients. The column and autosampler were maintained at temperatures of 40 and $8{ }^{\circ} \mathrm{C}$, respectively. The injection volume was $5 \mu \mathrm{L}[63,64]$.

All the separated peptide fractions were analyzed using a Thermo Orbitrap Fusion ${ }^{\mathrm{TM}}$ (Thermo Fisher Scientific, Waltham, MA, USA) mass spectrometer. The data were acquired at a resolution of 120,000 (@200 m/z) for full MS scans, followed by a high-energy-collision dissociation (HCD) fragmentation and detection of the fragment ions in the ion trap. The MS parameters were set as follows. Full Scan for MS: resolution (@ m/z 200) 120,000; scan range $(\mathrm{m} / z)$ : 350-1550; max injection (ms): 50; and automatic gain control (AGC) target: $2.00 \times 10^{5}$. Data-dependent MS/MS: Fragmentation HCD; NCE (\%): 35; detector type: Orbitrap; AGC target: $5.00 \times 10^{4}$; max injection (ms): 35; and dynamic exclusion (s): 60. All acquisitions and data analyses were controlled using the Progenesis QI for proteomics v3.0 (QIP) (Waters, Great Bookham, UK) and Mascot v2.5.1 (Matrix Science, London, UK) software.

LC/MS peptides mass spectrogram fingerprint method was validated under the regulation of Chinese Pharmacopoeia Commission. Seven different ions (RT $4.29 \mathrm{~min}, \mathrm{~m} / z$ 330.1976; RT $7.47 \mathrm{~min}$, 
$m / z$ 508.2743; RT $10.52 \mathrm{~min}, m / z$ 615.3333; RT $14.47 \mathrm{~min}, m / z$ 577.2941; RT $20.56 \mathrm{~min}, m / z$ 218.2128; RT $26.49 \mathrm{~min}, m / z$ 802.4413; and RT $31.95 \mathrm{~min}, m / z$ 246.2455) were selected for repeatability, precision, and stability, because the detected ion intensities were generated using the RT and $m / z$ data pairs in LC/MS peptides mass spectrogram. In six mass spectrograms of the same sample solution, the RSD values of retention time and exact mass of seven ions were less than $1.0 \%$. This suggested that the precision of method was better. In six mass spectrograms of six sample solutions prepared from the same sample, the RSD values of retention time and exact mass of seven ions were also less than $1.0 \%$, and it revealed the repeatability of the method was better. The RSD values of retention time and exact mass of seven ions detected in $0,2,4,6,8$, and $10 \mathrm{~h}$ were less than $1.2 \%$, which showed the sample solution was quite stable within $10 \mathrm{~h}$.

\subsection{Multivariate Data Analyses}

Progenesis QIP was used to analyze the raw data. The following parameters were employed: retention time range: 1.0-61.0 min; detected mass range: 100-2000 Da; mass tolerance: 0.05 Da; noise elimination level: 6.00; intensity threshold: 100 counts; mass window: $0.05 \mathrm{amu}$; and retention time (RT) window: $0.2 \mathrm{~min}$. No specific mass or adduct was excluded. A list of the detected peak intensities was generated using the RT and $m / z$ data pairs. Ions in different samples were considered to be identical when they demonstrated identical RT (tolerance of $0.2 \mathrm{~min}$ ) and $\mathrm{m} / \mathrm{z}$ values (tolerance of $0.05 \mathrm{Da}$ ). The ion intensities for each detected peak were normalized against the sum of the peak intensities within that sample using Progenesis QIP. The resulting three-dimensional data comprising of the peak number (RT- $m / z$ pair), sample name, and ion intensity were analyzed via unsupervised PCA. All variables were pareto-scaled prior to analysis. The scheme of the developed method was shown in Figure 5.

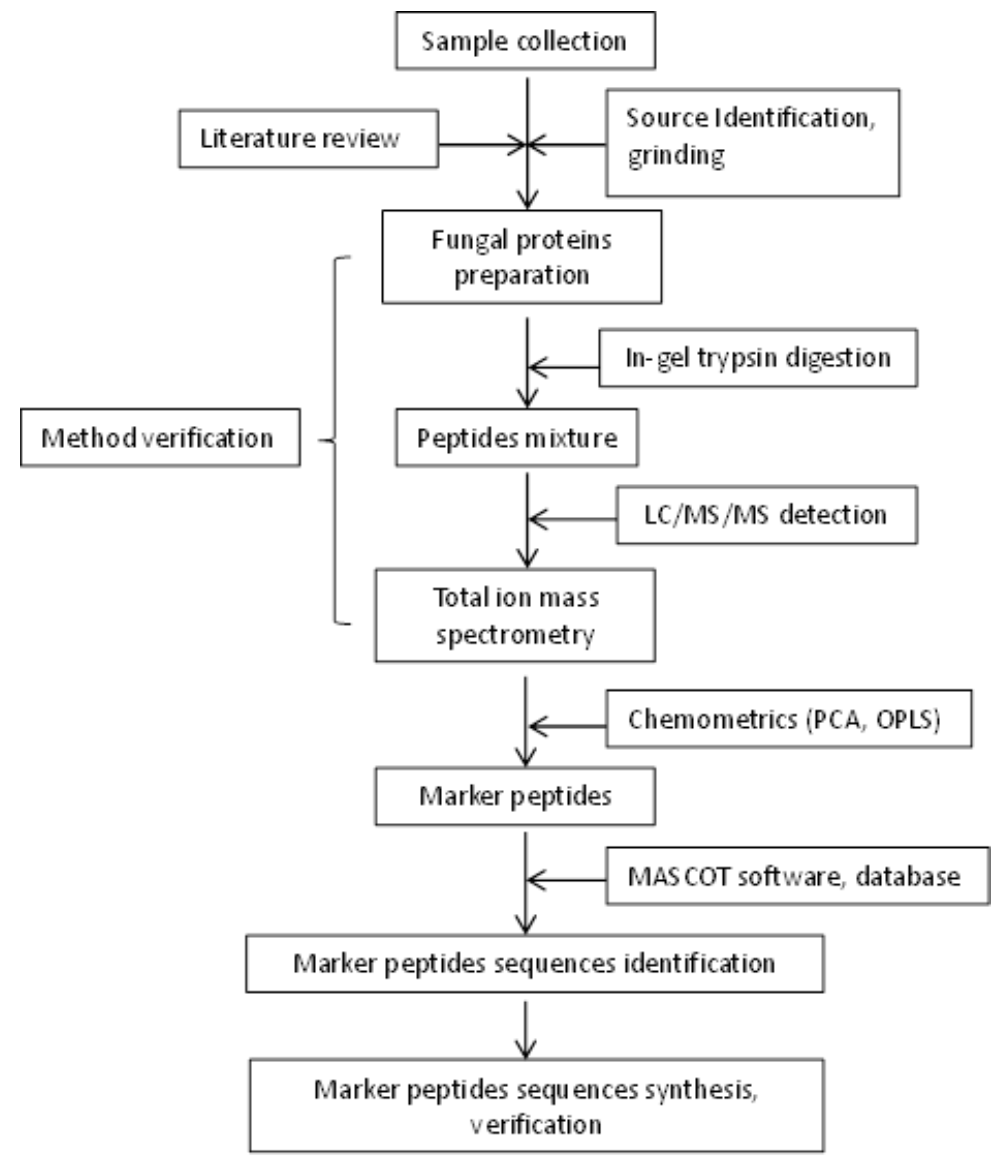

Figure 5. Scheme of the developed method. 


\section{Conclusions}

In this work, we established an efficient method that employs UPLC/Orbitrap-Fusion-MS/MS coupled with chemometrics for the identification of wild $O$. sinensis and four cultured $O$. mycelia products by identifying the marker peptide. This approach allowed for the profiling of the details of each sample so that the different marker peptides could be detected. Hence, the marker peptides could be used as powerful indexes for the identification of these mycelia and to distinguish the different mycelia in mixtures. The present approach provided a foundation for detecting the ion pairs, which came from parent ion and fragment ion of marker peptides using the MRM mode by LC/MS/MS and for developing the sensitive, stable, rapid quality control standard of the valuable Chinese medicine $O$. sinensis and its various cultured mycelia products.

Acknowledgments: This work was partly supported by grants from the project "The Platform of Quality Safety Inspection and Risk Control Technology Research of Traditional Chinese Medicine" (Grant No. 2014ZX09304-307-02) from the Important Program of the Ministry of Science and Technology of the People's Republic of China. Additionally, we sincerely thank engineer Haiwei Xi from Waters Technology Co., Ltd. (Shanghai, China) and Professor Yuanming Luo from the Institute of Microbiology, Chinese Academy of Sciences for their expert technical assistance.

Author Contributions: Ping Zhang carried out the experimental work and wrote the paper. Saina $\mathrm{Li}$ and Juan Li acquired and analyzed the data. Feng Wei and Xianlong Cheng collected the test samples, and Guifeng Zhang interpreted the data. Shuangcheng Ma and Bin Liu conceived and designed the work and provided guidance for the implementation of the experimental scheme.

Conflicts of Interest: The authors declare no conflict of interest. The funding sponsors had no role in the design of the study; in the collection, analyses, or interpretation of data; in the writing of the manuscript; or in the decision to publish the results.

\section{References}

1. Zhou, L.; Hao, Q.X.; Wang, S.; Kang, C.Z.; Yang, W.Z.; Guo, L.P. Study on distribution of five heavy metal elements in different parts of Cordyceps sinensis by microwave digestion ICP-MS. China J. Chin. Mater. Med. 2017, 42, 2934-2938. [CrossRef]

2. Lee, E.J.; Jang, K.H.; Im, S.Y.; Farooq, M.; Farhoudi, R.; Lee, D.J. Physico-chemical properties and cytotoxic potential of Cordyceps sinensis metabolites. Nat. Prod. Res. 2015, 29, 455-459. [CrossRef] [PubMed]

3. Panda, A.K.; Swain, K.C. Traditional uses and medicinal potential of Cordyceps sinensis of Sikkim. J. Ayurveda Integr. Med. 2011, 2, 9-13. [CrossRef] [PubMed]

4. Bao, Z.D.; Wu, Z.G.; Zheng, F. Amelioration of aminoglycoside nephrotoxicity by Cordyceps sinensis in old patients. Chin. J. Integr. Tradit. West. Med. 1994, 14, 271-273.

5. Bao, T.T.; Wang, G.F.; Yang, J.L. Pharmacological actions of Cordyceps sinensis. Chin. J. Mod. Dev. Tradit. Med. 1988, 8, 325-326, 352-354.

6. Buenz, E.J.; Bauer, B.A.; Osmundson, T.W.; Motley, T.J. The traditional Chinese medicine Cordyceps sinensis and its effects on apoptotic homeostasis. J. Ethnopharmacol. 2005, 96, 19-29. [CrossRef] [PubMed]

7. Buenz, E.J.; Weaver, J.G.; Bauer, B.A.; Chalpin, S.D.; Badley, A.D. Cordyceps sinensis extracts do not prevent Fas-receptor and hydrogen peroxide-induced T-cell apoptosis. J. Ethnopharmacol. 2004, 90, 57-62. [CrossRef] [PubMed]

8. Zhao, X.; Li, L. Cordyceps sinensis in protection of the kidney from cyclosporine A nephrotoxicity. Chin. Med. J. 1993, 73, 410-412, 447.

9. Illana Esteban, C. Cordyceps sinensis, a fungi used in the Chinese traditional medicine. Rev. Iberoam. Micol. 2007, 24, 259-262. [CrossRef]

10. Jahan-Abad, A.J.; Morteza-Zadeh, P.; Negah, S.S.; Gorji, A. Curcumin attenuates harmful effects of arsenic on neural stem/progenitor cells. Avicenna J. Phytomed. 2017, 7, 376-388.

11. Cao, L.; Ye, Y.; Han, R. Fruiting body production of the medicinal Chinese caterpillar mushroom, Ophiocordyceps sinensis (Ascomycetes), in artificial medium. Int. J. Med. Mushrooms 2015, 17, 1107-1112. [CrossRef] [PubMed]

12. Zhou, X.W.; Li, L.J.; Tian, E.W. Advances in research of the artificial cultivation of Ophiocordyceps sinensis in China. Crit. Rev. Biotechnol. 2014, 34, 233-243. [CrossRef] [PubMed] 
13. Yao, Y.S.; Zhu, J.S. Indiscriminate use of Latin name for natural Cordyceps sinensis insect-fungi complex and multiple Ophiocordyceps sinensis fungi. China J. Chin. Mater. Med. 2016, 41, 1361-1366. [CrossRef]

14. Zhu, J.S.; Halpern, G.M.; Jones, K. The scientific rediscovery of an ancient Chinese herbal medicine: Cordyceps sinensis: Part I. J. Altern. Complement. Med. 1998, 4, 289-303. [CrossRef] [PubMed]

15. Chen, Y.Q.; Wang, N.; Qu, L.; Li, T.; Zhang, W. Determination of the anamorph of Cordyceps sinensis inferred from the analysis of the ribosomal DNA internal transcribed spacers and 5.8S rDNA. Biochem. Syst. Ecol. 2001, 29, 597-607. [CrossRef]

16. Liu, Z.Q.; Lin, S.; Baker, P.J.; Wu, L.F.; Wang, X.R.; Wu, H.; Xu, F.; Wang, H.Y.; Brathwaite, M.E.; Zheng, Y.G. Transcriptome sequencing and analysis of the entomopathogenic fungus Hirsutella sinensis isolated from Ophiocordycepssinensis. BMC Genom. 2015, 16, 106. [CrossRef]

17. Chen, S.J.; Yin, D.H.; Li, L.; Zhou, X.L.; Za, X. Studies on anamorph of Cordyceps sinensis (Berk) from Naqu Tibet. China J. Chin. Mater. Med. 2001, 26, 453-454.

18. Yang, J.L.; Xiao, W.; He, H.X.; Zhu, H.X.; Wang, S.F.; Cheng, K.D.; Zhu, P. Molecular phylogenetic analysis of Paecilomyces hepiali and Cordyceps sinensis. Acta Pharm. Sin. 2008, 43, 421-426. [CrossRef] [PubMed]

19. Leung, P.H.; Zhang, Q.X.; Wu, J.Y. Mycelium cultivation, chemical composition and antitumour activity of a Tolypocladium sp. fungus isolated from wild Cordyceps sinensis. J. Appl. Microbiol. 2006, 101, 275-283. [CrossRef] [PubMed]

20. Balon, T.W.; Jasman, A.P.; Zhu, J.S. A fermentation product of Cordyceps sinensis increases whole-body insulin sensitivity in rats. J. Altern. Complement. Med. 2002, 8, 315-323. [CrossRef] [PubMed]

21. Zan, K.; Huang, L.L.; Guo, L.N.; Liu, J.; Zheng, J.; Ma, S.C.; Qian, Z.M.; Li, W.J. Comparative study on specific chromatograms and main nucleosides of cultivated and wild Cordyceps sinensis. China J. Chin. Mater. Med. 2017, 42, 3957-3962. [CrossRef]

22. Xie, C.; Xu, N.; Shao, Y.; He, Y. Using FT-NIR spectroscopy technique to determine arginine content in fermented Cordyceps sinensis mycelium. Spectrochim. Acta Part A Mol. Biomol. Spectrosc. 2015, 149, 971-977. [CrossRef] [PubMed]

23. Li, S.P.; Yang, F.Q.; Tsim, K.W. Quality control of Cordyceps sinensis, a valued traditional Chinese medicine. J. Pharm. Biomed. Anal. 2006, 41, 1571-1584. [CrossRef] [PubMed]

24. Ko, Y.F.; Liau, J.C.; Lee, C.S.; Chiu, C.Y.; Martel, J.; Lin, C.S.; Tseng, S.F.; Ojcius, D.M.; Lu, C.C.; Lai, H.C.; et al. Isolation, culture and characterization of Hirsutella sinensis mycelium from caterpillar fungus fruiting body. PLoS ONE 2017, 12, e0168734. [CrossRef] [PubMed]

25. Yue, K.; Ye, M.; Lin, X.; Zhou, Z. The artificial cultivation of medicinal caterpillar fungus, Ophiocordyceps sinensis (Ascomycetes): A review. Int. J. Med. Mushrooms 2013, 15, 425-434. [CrossRef] [PubMed]

26. Guo, L.X.; Xu, X.M.; Hong, Y.H.; Li, Y.; Wang, J.H. Stable carbon isotope composition of the lipids in natural Ophiocordyceps sinensis from major habitats in China and its substitutes. Molecules 2017, 22, 1567. [CrossRef] [PubMed]

27. Du, C.; Zhou, J.; Liu, J. Identification of Chinese medicinal fungus Cordyceps sinensis by depth-profiling mid-infrared photoacoustic spectroscopy. Spectrochim. Acta Part A Mol. Biomol. Spectrosc. 2017, 173, 489-494. [CrossRef] [PubMed]

28. Au, D.; Wang, L.; Yang, D.; Mok, D.K.; Chan, A.S.; Xu, H. Application of microscopy in authentication of valuable Chinese medicine I-Cordyceps sinensis, its counterfeits, and related products. Microsc. Res. Tech. 2012, 75, 54-64. [CrossRef] [PubMed]

29. Teng, W.Z.; Song, J.; Meng, F.X.; Meng, Q.F.; Lu, J.H.; Hu, S.; Teng, L.R.; Wang, D.; Xie, J. Study on the detection of active ingredient contents of Paecilomyces hepiali mycelium via near infrared spectroscopy. Spectrosc. Spectr. Anal. 2014, 34, 2645-2651.

30. Hou, X.R.; Luan, L.J.; Cheng, Y.Y. Quantitative analysis of the nucleosides in Cordyceps sinensis with capillary zone electrophoresis. China J. Chin. Mater. Med. 2005, 30, 447-449.

31. Huang, L.F.; Guo, F.Q.; Liang, Y.Z.; Chen, B.M. Determination of adenosine and cordycepin in Cordyceps sinensis and C. militarris with HPLC-ESI-MS. China J. Chin. Mater. Med. 2004, 29, 762-764.

32. Li, S.P.; Li, P.; Dong, T.T.; Tsim, K.W. Determination of nucleosides in natural Cordyceps sinensis and cultured Cordyceps mycelia by capillary electrophoresis. Electrophoresis 2001, 22, 144-150. [CrossRef]

33. Xie, J.W.; Huang, L.F.; Hu, W.; He, Y.B.; Wong, K.P. Analysis of the main nucleosides in Cordyceps sinensis by LC/ESI-MS. Molecules 2010, 15, 305-314. [CrossRef] [PubMed] 
34. Guo, F.Q.; Li, A.; Huang, L.F.; Liang, Y.Z.; Chen, B.M. Identification and determination of nucleosides in Cordyceps sinensis and its substitutes by high performance liquid chromatography with mass spectrometric detection. J. Pharm. Biomed. Anal. 2006, 40, 623-630. [CrossRef] [PubMed]

35. Zhang, Y.; Xu, L.; Zhang, S.; Liu, X.; An, Z.; Wang, M.; Guo, Y. Genetic diversity of Ophiocordyceps sinensis, a medicinal fungus endemic to the Tibetan Plateau: Implications for its evolution and conservation. BMC Evol. Biol. 2009, 9, 290. [CrossRef] [PubMed]

36. Lam, K.Y.C.; Chan, G.K.L.; Xin, G.Z.; Xu, H.; Ku, C.F.; Chen, J.P.; Yao, P.; Lin, H.Q.; Dong, T.T.X.; Tsim, K.W.K. Authentication of Cordyceps sinensis by DNA analyses: Comparison of ITS sequence analysis and RAPD-derived molecular markers. Molecules 2015, 20, 22454-22462. [CrossRef] [PubMed]

37. Liang, H.H.; Cheng, Z.; Yang, X.L.; Li, S.; Ding, Z.Q.; Zhou, T.S.; Zhang, W.J.; Chen, J.K. Genetic diversity and structure of Cordyceps sinensis populations from extensive geographical regions in China as revealed by inter-simple sequence repeat markers. J. Microbiol. 2008, 46, 549-556. [CrossRef] [PubMed]

38. Schiavone, N.M.; Sarver, S.A.; Sun, L.; Wojcik, R.; Dovichi, N.J. High speed capillary zone electrophoresis-mass spectrometry via an electrokinetically pumped sheath flow interface for rapid analysis of amino acids and a protein digest. J. Chromatogr. B Anal. Technol. Biomed. Life Sci. 2015, 991, 53-58. [CrossRef] [PubMed]

39. Lee, S.H.; Matsushima, K.; Miyamoto, K.; Oe, T. UV irradiation-induced methionine oxidation in human skin keratins: Mass spectrometry-based non-invasive proteomic analysis. J. Proteom. 2016, 133, 54-65. [CrossRef] [PubMed]

40. Li, C.H.; Zuo, H.L.; Zhang, Q.; Wang, F.Q.; Hu, Y.J.; Qian, Z.M.; Li, W.J.; Xia, Z.N.; Yang, F.Q. Analysis of soluble proteins in natural Cordyceps sinensis from different producing areas by sodium dodecyl sulfate-polyacrylamide gel electrophoresis and two-dimensional electrophoresis. Pharmacogn. Res. 2017, 9, 34-38. [CrossRef]

41. Hu, S.; Qiu, N.; Liu, Y.; Zhao, H.; Gao, D.; Song, R.; Ma, M. Identification and comparative proteomic study of quail and duck egg white protein using 2-dimensional gel electrophoresis and matrix-assisted laser desorption/ionization time-of-flight tandem mass spectrometry analysis. Poult. Sci. 2016, 95, 1137-1144. [CrossRef] [PubMed]

42. Zhang, H.; Gan, J.; Shu, Y.Z.; Humphreys, W.G. High-resolution mass spectrometry-based background subtraction for identifying protein modifications in a complex biological system: Detection of acetaminophen-bound microsomal proteins including argininosuccinate synthetase. Chem. Res. Toxicol. 2015, 28, 775-781. [CrossRef] [PubMed]

43. Legg, K.M.; Powell, R.; Reisdorph, N.; Reisdorph, R.; Danielson, P.B. Verification of protein biomarker specificity for the identification of biological stains by quadrupole time-of-flight mass spectrometry. Electrophoresis 2017, 38, 833-845. [CrossRef] [PubMed]

44. Jin, L.; Wang, D.; Gooden, D.M.; Ball, C.H.; Fitzgerald, M.C. Targeted mass spectrometry-based approach for protein-ligand binding analyses in complex biological mixtures using a phenacyl bromide modification strategy. Anal. Chem. 2016, 88, 10987-10993. [CrossRef] [PubMed]

45. Jiang, L.; Liu, Q.; Hu, D.; Xu, H.; Wang, H. Identification of a new protein from silkworm pupas by biological mass spectrometry. In Proceedings of the International Conference of the IEEE Engineering in Medicine and Biology Society (EMBC), Shanghai, China, 1-4 September 2005; Volume 6, pp. 5709-5711.

46. Magni, F.; Van Der Burgt, Y.E.M.; Chinello, C.; Mainini, V.; Gianazza, E.; Squeo, V.; Deelder, A.M.; Kienle, M.G. Biomarkers discovery by peptide and protein profiling in biological fluids based on functionalized magnetic beads purification and mass spectrometry. Blood Transfus. 2010, 8, s92-s97. [CrossRef] [PubMed]

47. Bai, K.C.; Sheu, F. A novel protein from edible fungi Cordyceps militaris that induces apoptosis. J. Food Drug Anal. 2018, 26, 21-30. [CrossRef] [PubMed]

48. Zhou, X.; Gong, Z.; Su, Y.; Lin, J.; Tang, K. Cordyceps fungi: Natural products, pharmacological functions and developmental products. J. Pharm. Pharmacol. 2009, 61, 279-291. [CrossRef] [PubMed]

49. Feng, K.; Wang, S.; Hu, D.J.; Yang, F.Q.; Wang, H.X.; Li, S.P. Random amplified polymorphic DNA (RAPD) analysis and the nucleosides assessment of fungal strains isolated from natural Cordyceps sinensis. J. Pharm. Biomed. Anal. 2009, 50, 522-526. [CrossRef] [PubMed]

50. Liu, Y.; Wang, J.; Wang, W.; Zhang, H.; Zhang, X.; Han, C. The chemical constituents and pharmacological actions of Cordyceps sinensis. Evid. Based Complement. Altern. Med. 2015, 2015. [CrossRef] 
51. Hu, H.; Xiao, L.; Zheng, B.; Wei, X.; Ellis, A.; Liu, Y.M. Identification of chemical markers in Cordyceps sinensis by HPLC-MS/MS. Anal. Bioanal. Chem. 2015, 407, 8059-8066. [CrossRef] [PubMed]

52. Bedlovičová, Z.; Ungvarská, L.M.; Salayová, A.; Harvanová, J.; Očenáš, P. Determination of biologically active compounds in the fungi of the genus Cordyceps sinensis by HPLC and NMR. CeskaSlov. Farm. 2015, 64, 202-205.

53. Zhang, L.; Ge, Y.; Li, J.; Hao, J.; Wang, H.; He, J.; Gao, X.M.; Chang, Y.X. Simultaneous determination of columbianetin- $\beta$-d-glucopyranoside and columbianetin in a biological sample by high-performance liquid chromatography with fluorescence detection and identification of other columbianetin- $\beta$-d-glucopyranoside metabolites by ultra high-performance liquid chromatography coupled with quadrupole-time of flight mass spectrometry. J. Pharm. Biomed. Anal. 2018, 153, 221-231. [CrossRef] [PubMed]

54. Woolman, M.; Gribble, A.; Bluemke, E.; Zou, J.; Ventura, M.; Bernards, N.; Wu, M.; Ginsberg, H.; Das, S.; Vitkin, A.; et al. Optimized Mass Spectrometry Analysis Workflow with Polarimetric Guidance for ex vivo and in situ Sampling of Biological Tissues. Sci. Rep. 2017, 7, 468. [CrossRef] [PubMed]

55. Zhang, S.; Lai, X.; Wu, C.; Wang, S.; Chen, X.; Huang, J.; Yang, G. Application of Differential Proteomic Analysis to Authenticate Ophiocordyceps sinensis. Curr. Microbiol. 2016, 72, 337-343. [CrossRef] [PubMed]

56. Zhang, H.X.; Qian, Z.M.; Yao, S.U.; Liu, X.Z.; Wen, J.L.; Dong, C.H. Comparative analyses of proteomic profile at different development stages of Chinese cordyceps by iTRAQ-coupled 2D LC-MSMS. Microbiology 2012, 39, 853-864.

57. Ashoub, A.; Berberich, T.; Beckhaus, T.; Bruggemann, W. A competent extraction method of plant proteins for 2-D gel electrophoresis. Electrophoresis 2011, 32, 2975-2978. [CrossRef] [PubMed]

58. Salem, M.; Bernach, M.; Bajdzeienko, K.; Giavalisco, P. A Simple Fractionated Extraction Method for the Comprehensive Analysis of Metabolites, Lipids, and Proteins from a Single Sample. J. Vis. Exp. 2017, 124. [CrossRef] [PubMed]

59. Tan, N.J.; Daim, L.D.; Jamil, A.A.; Mohtarrudin, N.; Thilakavathy, K. An effective placental cotyledons proteins extraction method for 2D gel electrophoresis. Electrophoresis 2017, 38, 633-644. [CrossRef] [PubMed]

60. Huynh, M.L.; Russell, P.; Walsh, B. Tryptic digestion of in-gel proteins for mass spectrometry analysis. Methods Mol. Biol. 2009, 519, 507-513. [CrossRef] [PubMed]

61. Albright, J.C.; Dassenko, D.J.; Mohamed, E.A.; Beussman, D.J. Identifying gel-separated proteins using in-gel digestion, mass spectrometry, and database searching: Consider the chemistry. Biochem. Mol. Biol. Educ. 2009, 37, 49-55. [CrossRef] [PubMed]

62. Lill, J.R.; Nesatyy, V.J. Microwave-assisted protein staining, destaining, and in-gel/in-solution digestion of proteins. Methods Mol. Biol. 2012, 869, 521-532. [CrossRef] [PubMed]

63. Guo, L.; Wang, Q.; Weng, L.; Hauser, L.A.; Strawser, C.J.; Rocha, A.G.; Dancis, A.; Mesaros, C.; Lynch, D.R.; Blair, I.A. Liquid Chromatography-High Resolution Mass Spectrometry Analysis of Platelet Frataxin as a Protein Biomarker for the Rare Disease Friedreich's Ataxia. Anal Chem. 2018, 90, 2216-2223. [CrossRef] [PubMed]

64. Randall, D.R.; Park, P.S.; Chau, J.K. Identification of altered protein abundances in cholesteatoma matrix via mass spectrometry-based proteomic analysis. J. Otolaryngol. Head Neck Surg. 2015, 44, 50. [CrossRef] [PubMed]

Sample Availability: Samples of the compounds marker peptides of TLLEAIDSIEPPK, AVLSDAITLVR, FAELLEK, and LESVVTSFTK are available from the authors.

(C) 2018 by the authors. Licensee MDPI, Basel, Switzerland. This article is an open access article distributed under the terms and conditions of the Creative Commons Attribution (CC BY) license (http:/ / creativecommons.org/licenses/by/4.0/). 